\title{
IMPACT OF SERVICE QUALITY, SATISFACTION AND PASSENGERS BEHAVIOUR OF FULL-SERVICE AIRLINES OPERATING IN THAILAND
}

\author{
Oraphan Decha
}

Suan Sunandha Rajabhat University, Bangkok, Thailand

\begin{abstract}
Airline companies today are faced with various challenges such as cutting price, managing fluctuating demand, and meeting quality requirements. In addition to these issues, intense competition in the global airline industry has intensified the importance of customer perception of service quality. Numerous studies demonstrate the dependence of airline's market share, revenues, positive word of mouth, and customer retention on consumer perception of service quality, and in turn, on customer satisfaction and loyalty. This paper explains the relationship between service quality, satisfaction and passenger behavior for full-services airlines operating in Thailand. The survey questionnaire was designed and administered to 110 respondents who all were passengers of these airlines. Our four hypotheses concerned such variables as service quality and passenger satisfaction, satisfaction and word of mouth, satisfaction and repurchase intention, and satisfaction and feedback. SERVPERF was used as the key instrument in our analysis. Top managers of fullservice airlines often tend to disregard high priority of quality components. Thus, they should be more aware of the importance of service quality and passenger's satisfaction in determining the behavioral intentions of passengers.
\end{abstract}

Keywords: service quality; customer satisfaction; customer behavior, full-services airlines; passengers.

\section{Introduction}

The airline industry was tightly regulated until 1978, when more and more private airlines started to emerge. Later on, low-cost airlines appeared and immediately attracted even more passengers into the industry (Belobaba et al., 2015). The aviation sector has become the most important segment in economic development of many nations. It plays a vital role in moving people and products from one place to another, domestically or internationally, but especially in case of long distance travel. In a highly competitive environment provision of high-quality services to passengers is the core competitive advantage for an airline's profitability and sustained growth. In the past decade, as the air transportation market has become even more challenging, many airlines have turned to focus on their service quality and increasing service satisfaction. Service quality influences a firm's

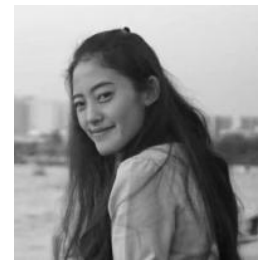

\section{Oraphan Decha}

MBA, Lecturer in College of Innovation and Management, Suan Sunandha Rajabhat University, Thailand.

Research interests: marketing, customer behavior, promotion

E-mail: oraphan.de@ ssru.ac.th 


\section{IMPACT OF SERVICE QUALITY, SATISFACTION}

competitive advantage as it guarantees retaining customer patronage, and with this comes a growing market share. Delivering high-quality service to passengers is essential for airline's survival, so airlines need to understand what passengers expect from their services.

The existing literature provides mixed evidence on the relationships between service quality, customer satisfaction and behavioural intentions across low-cost and full-service airlines' contexts. Loureiro and Fialho (2016) found that services of low-cost and full-service airlines are perceived similarly by the passengers, these authors were unable to uncover significant differences in the relationships between satisfaction and its antecedents as well as between behavioural intentions and their determinants across different types of airlines.

Behavioral intentions of customers are recognized in literature as a significant predictor of service enterprises' profitability (Reichheld \& Sasser, 1990; Anderson et al., 1994; Slater $\&$ Narver, 1995). Costs and revenues of firms are affected by repeated purchases, positive recommendation (the so-called word of mouth) and other forms of customer feedback. Moreover, there is sufficient amount of strong evidence to prove that service quality has either a direct influence on behavioral intentions of customers, or indirect influence on intentions, mediated through customer satisfaction (Zeithaml et al., 1996; Cronin et al., 2000).

\section{Passengers' perception of low-cost airlines and full-service carriers}

Several differentiating characteristics between low-cost and full-services airlines can be identified. While low-cost carriers provide no-frills services under a rather simplified regime of fare, full-service carriers focus on providing a wide range of pre-flight and onboard services in different services classes, thus employing a complex pricing structure (Chiou \& Chen, 2010; Loureiro \& Fialho, 2016; Reichmuth, 2008).

Table 1 - List of most popular full-cost carriers around the world (Source: made by the author)

\begin{tabular}{|c|c|}
\hline Airline & Country \\
\hline British Airways & United Kingdom \\
\hline China Airlines & Taiwan \\
\hline Thai Airways & Thailand \\
\hline Japan Airlines & Japan \\
\hline Singapore Airlines & Singapore \\
\hline Korean Air & South Korea \\
\hline Virgin Atlantics & Australia \\
\hline
\end{tabular}

Special characteristics of full-cost carriers (FCCs) are that they are typically use first airports, have flexibility in fleet management and offer various frequent flyer programs. They also provide various extra services to their customers, including online booking, self-checkin, no limitations on weight and/or number of checked-in bags. In addition, FCCs usually do not charge for extra food, priority seating and priority boarding, neither for flight entertainment. Some of the most popular airlines in the world are presented in Tab. 1. 


\section{Differences between operations of low-cost carriers (LCCs) and full-service carriers (FSCs)}

LCCs differ from FSCs in several key ways. Firstly, they differ in terms of network structures; besides, FSCs provide a much wider range of destinations, on both domestic and international directions. FSCs are able to include the largest aircrafts such as Boeing B747 or Airbus A380 in their fleets. The key downside of full-service carried is the complexity in planning of connecting flights and tight time frames. Thus, these airlines are often experiencing delays. Tab. 2 provides a summary of the differentiating characteristics between full-services and low-cost carriers.

Table 2 - Product features of low-cost and full-services carriers

(Source: made by the author)

\begin{tabular}{|c|c|c|}
\hline Product feature & Low-cost carriers & Full-service carriers \\
\hline Brand & One brand: low fare & Brand extensions: fare \& service \\
\hline Fares & Simplified fare structure & $\begin{array}{l}\text { Complex fare structure \& yield } \\
\text { management }\end{array}$ \\
\hline Distribution & Online and direct & Online, direct, via travel agents \\
\hline Check-in & Ticketless & Ticketless, IATA ticket contract \\
\hline Airports & Secondary & Primary \\
\hline Connections & Point-to-point & Interlining, code sharing, global \\
\hline Class & One class (high density) & Several classes \\
\hline Segmentation & Pay for convenience & Two-class system or several \\
\hline In-flight & No services & Variety \\
\hline Turnaround Time & 25 minutes turn-around & Medium to high: Union Contracts \\
\hline Ancillary services & Provided through sales & $\begin{array}{l}\text { Multiple integrated product. } \\
\text { Focus on the primary product }\end{array}$ \\
\hline Aircraft Type & Single Type & $\begin{array}{c}\text { Multiple Types } \\
\text { Complexity in scheduling }\end{array}$ \\
\hline Seating & $\begin{array}{l}\text { Small pitch, no } \\
\text { assignment }\end{array}$ & $\begin{array}{c}\text { Generous pitch, offering seat } \\
\text { assignment }\end{array}$ \\
\hline Customer Services & $\begin{array}{l}\text { Generally none or } \\
\text { limited number }\end{array}$ & Full service, offer reliability \\
\hline $\begin{array}{l}\text { Operational } \\
\text { Activities }\end{array}$ & $\begin{array}{l}\text { Focus on the core } \\
\text { (flying) }\end{array}$ & $\begin{array}{c}\text { Extension of activities, including } \\
\text { cargo }\end{array}$ \\
\hline
\end{tabular}

\section{Conceptual framework and Research hypotheses}

A conceptual model for this research in presented in Fig. 1. This model depicts certain hypothesized relationships between the constructs of service quality, customer satisfaction, and behavioral intention. 


\section{IMPACT OF SERVICE QUALITY, SATISFACTION}

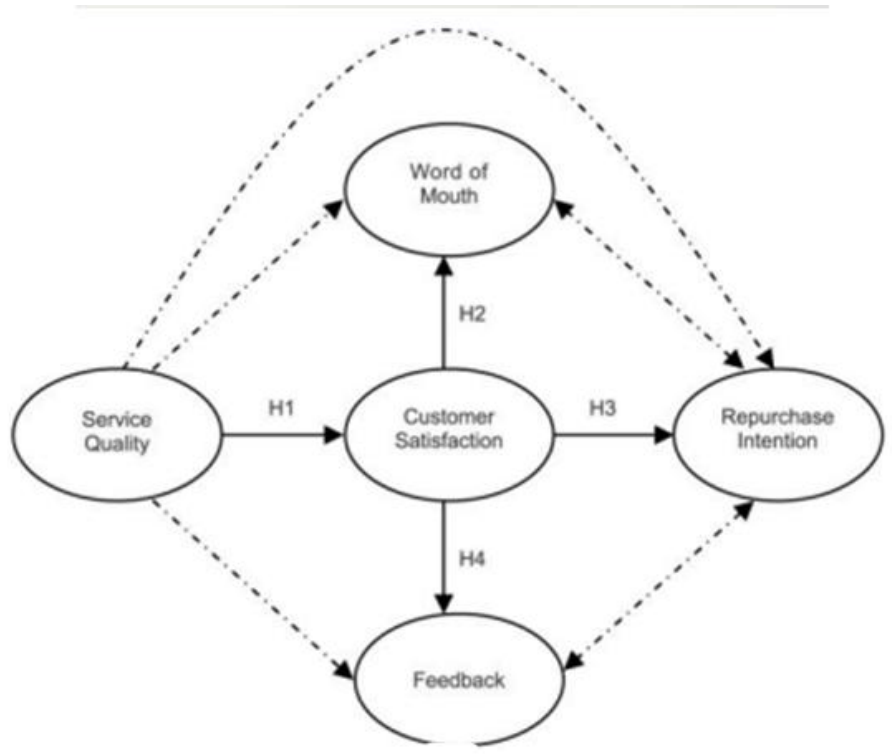

Figure 1 - Conceptual framework for the research (Source: made by the author)

\section{Hypotheses regarding service quality and satisfaction}

\section{H1. Perceived service quality positively influences passenger satisfaction}

Although commonly some sort of relationship between service quality and satisfaction is suspected in literature in any case, in relation to Thai FCCs specifically, to the best of our knowledge, nobody has ever posed a hypothesis that satisfaction is influenced by perceived service quality.

Passengers of airlines gather a great deal of their experience through direct experience (Powpaka et al., 1996). Tangible dimensions of the service delivery practice are essential in this experience because airlines usually have limited time for passenger interaction and customization of their services (Schmener, 1986).

\section{H2. Passenger satisfaction is positively influenced by positive word-of-mouth}

Although both satisfied and dissatisfied customers might choose to get involved in word-of-mouth activities, the related literature usually demonstrates that customers who are satisfied turn to positive word-of-mouth much more frequently than dissatisfied passengers turn to negative one.

\section{H3. Passenger satisfaction positively influences repurchase intention}

Satisfied customers are normally more loyal in terms of repurchase behavior unless changing costs are becoming high or better opportunities are available elsewhere. Anton (1996) explained that customers switch suppliers because they are not satisfied with the company's perceived worth, relative to the competition at the market. 


\section{H4. Passenger satisfaction negatively influences the level of feedback}

Customers lean to provide negative feedback when they are dissatisfied with the service. Nonetheless, if customers respect that the service provider has tried to improve the worst services or if they attribute the poor service to external causes, dissatisfaction and negative feedback are less likely to happen. In the case of airline services, passengers are often unable to identify the causes of poor servicing, therefore, they might not be able to realize whether flight delays are due to bad weather or due to maintenance failure on the part of the airline itself. Therefore, customers might use expectation or satisfaction as a proxy for the level of quality that they should receive.

\section{Sample and data collection}

The sample for this study is composed of the passengers who had flown on any of the full-cost carriers in Thailand in 2018. The passengers for the sample were selected using a quota sample method so that to ensure the sample is balanced enough and equal in representation of all full-cost carriers in accordance with the scope of their operations in terms of flights per week. The selected airlines were: Thai Airways, Bangkok Airways, and Thai Smile. The data were collected using primary data sources. Primary data were collected using structured questionnaires which consisted of 3 sections covering the following aspects: the choice of a full-cost airline; service quality, with the focus on SERVPERE instrument, satisfaction with the fare being reasonable, airline's services and the airline overall, and behavioral intention such as word-of-mouth, repurchase intention, and passenger feedback; finally, the third aspect was the demographic profile of the respondents. The questions were phrased as statements scored on the five-point Likert scale, from $1=$ strongly disagree to $5=$ strongly agree.

Questionnaires were distributed among the passengers waiting in the departure and arrival lounges of Suvarnabhumi International Airport in Bangkok. Also, there was an option of a web-link to the same online questionnaire. Such links have been sent via social channels -- Facebook and Line chat application.

The survey was administered during April-May 2018. The total of 110 completed questionnaires were received from the passengers: Thai Airways -- 52 persons, Bangkok Airways -- 48 persons, Thai Smile -- 12 persons, and also other airlines -- 2 persons. The mean age of the respondents was $26-35$ years, $45.5 \%$ of the respondents were female. $48.2 \%$ were Thai nationals, these Thai respondents had the average monthly income of 20,000$40,000 \mathrm{THB}$ at the time the study was conducted. The respondents made on average 2-5 flights in the preceding five years. Approximately half of all the respondents had travelled for visiting their family or friends, another third were travelling for leisure purposes, and the remainder were travelling with business or other formal purposes.

\section{Measurements}

\section{Service quality}

Service quality dimensions used in the study were developed based on a focus-group discussion with seven experienced customers of full-cost carriers; and then the SERVPERF instrument was applied (Cronin and Taylor, 1992). In the focus group, traditional dimensions of reliability, assurance, tangibility, empathy, and responsiveness were discussed to evaluate 


\section{IMPACT OF SERVICE QUALITY, SATISFACTION}

their appropriateness for measurement of service quality in the context of FCC services. The discussion resulted in generalization of four broad factor categories: (1) tangible factors such as newness of an airplane overall and seats in particular; (2) flight schedule factors such as convenience of routes in terms of scheduling, on-time departure and arrivals, and flight cancellation; (3) flight attendants, including their good attitude, helpfulness, promptness of service, and friendliness with passengers (4) ground staff -- high speed of servicing on the ground, time management and passenger satisfaction. All in all, the total of 21 items were initially developed for these four constructs (Q6, 7, 8 for tangibles, Q9, Q10, Q11, Q12 for the schedule, and Q13, Q14, Q15, Q16, Q17, Q18, Q19 for flight attendants, and finally for ground staff -- Q20, Q21, Q22, Q23, Q24, Q25, Q26). All these items were measured on a five-point Likert type scale (with $1=$ strongly disagree, $5=$ strongly agree).

\section{Satisfaction}

Passenger satisfaction was measured with three items: (1) satisfaction with fare; (2) satisfaction with services; (3) overall satisfaction with the airline. The items were developed from a value-based definition of customer satisfaction widely used in literature (for example, Heskett et al., 1994; Schneider and Bowen, 1995). All the items were measured on a fivepoint Likert type scale (with $1=$ strongly disagree, $5=$ strongly agree).

\section{Behavioral intention}

Items for feedback, word-of-mouth, and repurchase intention were adopted from Soderlund (1998). All these items were measured on a five-point Likert type scale (again, $1=$ strongly disagree, 5 = strongly agree).

\section{Data analysis}

Data were analyzed by means of using Statistical Package for Social Sciences (SPSS), version 18. The first sector covers frequencies' analysis of demographic factors (Table 3) such as gender; age; education; occupation, and income per month. Another frequencies' analysis covers the full-cost airline choices: which full-cost airline in Thailand, total times to flights in 5 years, purpose of travel, and tickets' purchase info. The next sector is descriptive analysis of statistical means, standard deviations, and correlation as they were calculated for all the constructs.

T-test was used to test the hypothesis and regression analysis was executed to examine the relationships between the variables. This is in line with what was used in similar empirical studies, for example, Pearson correlation and multiple regression analysis via Microsoft Excel. Reliability and validity were measured using Cronbach $\alpha$, this was the test for internal consistency for all the items under respective variables. Hair et al. (1998) advised that Cronbach's $\alpha$ coefficient over 0.6 is adequate for such research studies. Reliability of each construct was assessed by using the Cronbach $\alpha$ measure which was ranging from 0.604 to 0.863 , thus indicating that the scale is internally consistent and reasonably free of measurement error. To ensure the appropriateness of the study tool, a pilot study was also performed. 
Table 3 - Reliability of various service factors and satisfaction factors, author's own calculations

(Source: made by the author)

\begin{tabular}{|l|c|c|c|}
\hline Factor & $\begin{array}{c}\text { Number of } \\
\text { statements }\end{array}$ & Number of cases & Cronbach's $\alpha$ \\
\hline Tangibles & 3 & 110 & 0.712 \\
Flight schedule & 4 & 110 & 0.702 \\
Ground staff & 7 & 110 & 0.863 \\
Flight attendants & 7 & 110 & 0.823 \\
Passenger & 3 & 110 & 0.657 \\
satisfaction & 2 & 110 & 0.798 \\
Repurchase & 2 & 110 & 0.604 \\
intention & 2 & 110 & 0.688 \\
Word of mouth & & & \\
Feedback & & & \\
\end{tabular}

\section{Results and Discussion}

As shown in Tab. 4, the passengers were obviously content with the overall of airline services, as demonstrated by the mean satisfaction (Passenger satisfaction; PS1, PS2, PS3) score of 3.79 and the mean of service quality scoring between 3.45 (Ground staff; GS1, GS2, GS3, GS4, GS5, GS6, GS7) and 3.59 (Flight schedule; FS1, FS2, FS3, FS4, and Flight attendant; FA1, FA2, FA3, FA4, FA5, FA6, FA7), all on the five-point scales. When it comes to service quality, the respondents were least satisfied with the measurement of scheduling; its mean score is 3.59. The standard deviation on ground staff is 1.073 which is greater than for other dimensions. This indirectly points out to the fact that the respondents are inclined to have rather extreme views about the airlines' ground staff services, even though lower satisfaction ratings are prevailing. The respondents generally conferred a positive rating to behavioral intentions. More specifically, provision of feedback to service providers got the mean score of 3.62, the passengers' repeated purchase intention had the mean score of 3.63, and positive word-of-mouth communications to friends and families got the mean score of 3.55 .

The relationship between passenger satisfaction and feedback is relatively moderate ( $\mathrm{r}$ $=0.569$ ), and it is a positive relationship (opposite to the negative relationship commonly explained in literature, for the record). It is also clear from our study that satisfied airline passengers also provided feedback to airlines, however, with much lower level of intensity. The extremely strong relationship has been observed between satisfaction and behavioural intentions $(\mathrm{r}=0.557)$. 


\section{IMPACT OF SERVICE QUALITY, SATISFACTION}

\section{Descriptive Analysis}

Table 4 - Descriptive analysis of mean and standard deviations

(Source: made by the author)

\begin{tabular}{|c|c|c|c|c|c|}
\hline \multicolumn{6}{|c|}{ Descriptive Statistics } \\
\hline & $\mathrm{N}$ & $\begin{array}{c}\text { Minimu } \\
\mathrm{m}\end{array}$ & $\begin{array}{c}\text { Maximu } \\
\mathrm{m}\end{array}$ & Mean & $\begin{array}{c}\text { Std. } \\
\text { Deviation }\end{array}$ \\
\hline Tan1 & 110 & 1 & 5 & 3.77 & .864 \\
\hline $\operatorname{Tan} 2$ & 110 & 1 & 5 & 3.82 & .911 \\
\hline Tan3 & 110 & 1 & 5 & 3.62 & .908 \\
\hline FS1 & 110 & 1 & 5 & 3.38 & 1.049 \\
\hline FS2 & 110 & 1 & 5 & 3.66 & .911 \\
\hline FS3 & 110 & 1 & 5 & 3.72 & .900 \\
\hline FS4 & 110 & 1 & 5 & 3.29 & 1.199 \\
\hline GS1 & 110 & 1 & 5 & 3.79 & 1.024 \\
\hline GS2 & 110 & 1 & 5 & 3.73 & 1.149 \\
\hline GS3 & 110 & 1 & 5 & 3.25 & 1.119 \\
\hline GS4 & 110 & 1 & 5 & 3.52 & .896 \\
\hline GS5 & 110 & 1 & 5 & 2.73 & 1.172 \\
\hline GS6 & 110 & 1 & 5 & 3.63 & 1.039 \\
\hline GS7 & 110 & 1 & 5 & 3.51 & 1.115 \\
\hline FA1 & 110 & 1 & 5 & 3.39 & 1.024 \\
\hline FA2 & 110 & 1 & 5 & 3.79 & .879 \\
\hline FA3 & 110 & 1 & 5 & 3.65 & .841 \\
\hline FA4 & 110 & 1 & 5 & 3.50 & .916 \\
\hline FA5 & 110 & 1 & 5 & 3.45 & .973 \\
\hline FA6 & 110 & 1 & 5 & 3.64 & .974 \\
\hline FA7 & 110 & 1 & 5 & 3.69 & 1.064 \\
\hline PS1 & 110 & 1 & 5 & 3.81 & .840 \\
\hline PS2 & 110 & 1 & 5 & 3.73 & .877 \\
\hline PS3 & 110 & 1 & 5 & 3.83 & .833 \\
\hline RI1 & 110 & 1 & 5 & 3.69 & 1.064 \\
\hline $\mathrm{RI} 2$ & 110 & 1 & 5 & 3.56 & .914 \\
\hline WM1 & 110 & 2 & 5 & 3.62 & .928 \\
\hline WM2 & 110 & 1 & 5 & 3.48 & .965 \\
\hline FB1 & 110 & 1 & 5 & 3.52 & .896 \\
\hline FB2 & 110 & 1 & 5 & 3.72 & .900 \\
\hline $\begin{array}{l}\text { Valid N (list } \\
\text { wise) }\end{array}$ & 110 & & & & \\
\hline
\end{tabular}

Moreover, repurchase intention is demonstrated to have relation to word-of-mouth communication, which explains that passengers who were satisfied with the service were more likely to recommend the related positive sides to their families and friends. These findings provide empirical support for the fact that passengers' judgments of service quality of full-cost airlines in Thailand influences their level of satisfaction, and this level of satisfaction, in turn, influences their behavioral intentions. 


\section{Testing the hypotheses}

\section{H1. Perceived service quality positively influences passengers' satisfaction}

\section{Table 5 - Results of the R square analysis for $\mathrm{H} 1$}

(Source: made by the author)

\begin{tabular}{|c|c|c|c|c|c|c|}
\hline \multicolumn{5}{|c|}{ Model Summary } & & \\
\hline Model & $\mathrm{R}$ & R Square & $\begin{array}{l}\text { Adjusted R } \\
\text { Square }\end{array}$ & $\begin{array}{l}\text { Std. Error of } \\
\text { the Estimate }\end{array}$ & & \\
\hline 1 & $.771^{\mathrm{a}}$ & .594 & .579 & .41719 & & \\
\hline \multicolumn{5}{|c|}{$\begin{array}{l}\text { a. Predictors: (Constant) - Flight Attendance, Flight Schedule, Tangible, } \\
\text { Ground Staff }\end{array}$} & & \\
\hline \multicolumn{7}{|c|}{ ANOVAa } \\
\hline \multicolumn{2}{|c|}{ Model } & $\begin{array}{l}\text { Sum of } \\
\text { Squares }\end{array}$ & df & Mean Square & $\mathrm{F}$ & Sig. \\
\hline \multirow{3}{*}{1} & $\begin{array}{l}\text { Regress } \\
\text { ion }\end{array}$ & 26.776 & 4 & 6.694 & 38.461 & $.000^{\mathrm{b}}$ \\
\hline & $\begin{array}{l}\text { Residua } \\
1\end{array}$ & 18.275 & 105 & .174 & & \\
\hline & Total & 45.051 & 109 & & & \\
\hline
\end{tabular}

The table shows that $\mathrm{R}$ square $=0.594$. It means that the service quality variables (flight attendant, flight schedule, tangibles and ground staff) have positively influence on passenger satisfaction by approximately $59.4 \%$.

Table 6 - Results of the regression analysis for $\mathrm{H} 1$

(Source: made by the author)

\begin{tabular}{|c|c|c|c|c|c|}
\hline \multirow[t]{2}{*}{ Model } & Unstand & Coefficients & $\begin{array}{l}\text { Standardized } \\
\text { Coefficients }\end{array}$ & $\mathrm{t}$ & Sig. \\
\hline & $\mathrm{B}$ & Std. Error & Beta & & \\
\hline (Constant) & .882 & .245 & & 3.599 & .000 \\
\hline Tangible & .281 & .078 & .312 & 3.614 & .000 \\
\hline Flight Schedule & .054 & .069 & .063 & .785 & .434 \\
\hline Ground Staff & .115 & .082 & .143 & 1.401 & .164 \\
\hline Flight & .353 & .104 & .366 & 3.384 & .001 \\
\hline
\end{tabular}

The standardized coefficients (Beta) of the four paths (flight attendants, flight schedule, tangible, and ground staff) were $0.366,0.063,0.312$ and, 0.143 respectively. The critical ratio (t-values) for these paths was $3.384,0.785,3.614$, and 1.401 respectively.

These findings provide support for $\mathrm{H} 1$. The tangible dimension (aircraft convenience) is the most important aspect of service quality when it comes to passenger satisfaction, whereas the least important is the flight schedule group. 


\section{IMPACT OF SERVICE QUALITY, SATISFACTION}

\section{H2. Passenger satisfaction positively influences positive word-of-mouth}

For $\mathrm{H} 2$, the $\mathrm{R}$ square $=0.392$. It means that the passenger service variable components have rather positively influences on positive word-of-mouth by approximately $39.2 \%$.

The standardized coefficient (Beta) for passenger satisfaction was 0.626. The critical ratio ( $\mathrm{t}$-value) for these paths was 8.350 . These findings provide support for $\mathrm{H} 2$. It is apparent that satisfied passengers tend to provide strongly positive word-of-mouth.

\section{H3. Passenger satisfaction positively influences positively repurchase intention}

The model summary shows that $\mathrm{R}$ square $=0.310$. It means that passenger satisfaction positively influences the repurchase intentions by approximately $31 \%$.

The standardised coefficient (Beta) for passenger satisfaction is 0.557 . The critical ratio (t-value) for these paths was 6.967. These findings provide support for H3. It is apparent that under the significant level of satisfaction, customers are more likely to travel with the same airline in their next journeys.

\section{H4. Passenger satisfaction negatively influences the level of feedback}

The tables show that $\mathrm{R}$ square $=0.318$. This means that passenger satisfaction has negatively influence on the level of feedback by approximately $31.8 \%$.

The standardized coefficients (Beta) for passenger satisfaction were 0.569 . The critical ratio ( $\mathrm{t}$-value) for these paths was 7.193. These findings do not provide support for $\mathrm{H} 4$. It is apparent that passengers satisfied with the service quality are more likely to provide feedback, which is opposed to the findings commonly reported in other literature sources.

\section{Conclusions}

Various characteristics of full-cost airlines have added more variety to the airline industry and made it more competitive and attracting to customers globally. The resulting dynamics seems to cause serious changes in both business models and market conditions, and this should be considered as an extra chance for both airlines and their passengers. Although the passenger has now a huge choice, the airlines that are most receptive and creative will turn out to be most successful too. However, airlines must be cautious and they should not forget once again that at the end it is the passengers who are making the choice. Therefore, ancillary services and revenues from them must remain optional and must form only a smaller part of the final ticket price. Additional charges for the services that are not really seen as optional by passengers will be breaking the relationship between the passenger and the airline. Finally, passengers will be buying tickets from the airlines which the ticket is perceived as a fair deal. At today's market, which offers a variety of alternative business models there are always competitors who will do business differently and thus offer something interesting to potential passengers.

The three studied here full-cost airlines in Thailand have encountered persistent financial shortages. There is a whole range of factors threatening the revenues of full-cost airlines and the latter have little control of them: growing fuel prices, changing market positions of the leading full-service airline (FSCs), political factors etc. Besides that, there is sufficient evidence that even the most prosperous among full-cost airlines in the other parts of the world have started offering lower fares to their passengers and have also become more responsive in terms of service quality provided to passengers. At the same time, Thai full- 
cost airlines have been not that active in adopting the measures to improve their service quality section and passenger satisfaction. The current study has been investigating whether the impact of service quality and satisfaction influences passengers' behavioural intentions including word-of-mouth, repurchase intention, and provision of feedback in the case of fullcost airlines operating in Thailand. Our study cover primarily such airlines as Thai Airways and Bangkok Airway, though some data on a few other has been also included for the sake of variety.

The findings of our study are compatible with that of prior research in conclusion that the impact of service quality is an important determinant for customer satisfaction with service quality and also for satisfaction influencing as behavioral intention, including wordof-mouth, repurchase intentions and customer feedback.

More specially, passengers demonstrate overall satisfaction with the four dimensions of service quality which are examined under such parameters: tangibles, flight schedule, flight attendants, and ground staff. It is interesting to mention that the dimension of flight scheduling got the lowest mean rating, and this result is very different from other dimensions. Nonetheless, correlation between flight scheduling and passenger satisfaction is average, and this implies that there should be more improvement in flight schedule as this is a significant problem that requires attention from all Thai full-cost airlines, actually. The dimensions of flight attendants and tangibles have demonstrated to have significant influence on the construct of satisfaction. Therefore, we can conclude that the service offered by both ground staff and flight attendants has very strong impact on passenger satisfaction, at least in this specific case.

In contrast to the findings reported in other literature, the current study has found a positive relationship between the level of satisfaction and the feedback provided to service provider. In other words, FCC passengers provide positive feedback if their expectations are met (and negative feedback if unmet, but at a very low level) (Vorasiha, 2018).

Moreover, our study finds that passengers who do not intend to provide negative feedback are likely to not just remain silent but they turn to other airlines. Examination of the connection among service quality, satisfaction and behavioural intentions has exposed that satisfaction plays a direct role in improving passengers' intentions to become involved in word-of-mouth activities and repurchasing. However, satisfaction had a weaker correlation with the provision of feedback; unsatisfied customers are mostly inclined to move to other airlines, providing no negative feedback as such. Passengers who get engaged in the word-ofmouth activities were found to become loyal customers subsequently. Having more satisfied passengers is thus shown to be important in developing loyalty among passengers.

\section{Implications}

The findings of this study have significant implications for managers of full-cost airlines, especially in terms of quality of services that could be provided and also in terms of significant influence that satisfaction has on the behavioral intentions of customers. Managers should be aware that, among various dimensions of service quality, reliability of flights' schedule was found to be especially significant in supporting satisfaction among customers of Thai full-cost airlines. It is apparent that timely operation of flights is critical for customer satisfaction. In addition, satisfaction of passengers is found to be significantly influenced by the performance of flight attendants and the quality of the aircraft interior 


\section{IMPACT OF SERVICE QUALITY, SATISFACTION}

including technology, aircraft types, and comfortable seats. It is thus apparent that managers of full-cost airlines in Thailand could improve customer satisfaction by maintaining or improving the quality of services offered by their flight attendants and the quality of the tangibles connected with the service. It is also apparent that the use of customer complaints (received through web sites or other means of communication) as a performance pointer is supported by the current findings. Finally, satisfaction of passengers in this study has been found to have a significant relationship with feedback.

\section{Limitations and suggestions}

The study has several acknowledged limitations. The first of them is related to generalizability of the findings. Although the study had a rather large sample, one need to be cautious in applying the findings in the context other than that of Thai full-cost airlines because: people who are travelling with full-cost airlines in Thailand represent a relatively high-income group of Thai population; also, Thailand, unlike some other South-East Asian countries, is offering good means of transportation to all parts of the country. Secondly, passenger satisfaction in this study was rather narrowly understood as there are only four dimensions of service quality here.

Although $54.5 \%$ of variation in passenger satisfaction was explained by the four service dimensions studied here, the remaining $45.5 \%$ can be explained by some other factors, actually, that were examined in this study but the result is very low, or were not examined at all. For example, passenger satisfaction might be influenced by such factors as financial incentives for flight delays, the image of a specific full-cost airlines etc. Future studies might include these and other factors into account while assessing their explanatory powers. The third limitation concerns the method of analysis used in this study. The findings regarding the cause-effect relationships among service quality, passenger satisfaction, and behavioural intentions in this study are provisional. Further research should be conducted with panel data so that to investigate these causal relationships in much more detail (Biddle and Martin, 1987).

\section{Acknowledgment}

The authors would like to thank the Research and Development Institute, College of Innovation and Management, Suan Sunandha Rajabhat University, Bangkok, Thailand for financial support.

\section{References:}

Anderson, E.W., Fornell, C. \& Lehmann, D.R. (1994). Customer satisfaction, market share and profitability: findings from Sweden, Journal of Marketing, 58: 53-66.

Anton, J. (1996). Customer Relationship Management: Making Hard Decisions with Soft Numbers, Prentice-Hall, Upper Saddle River, NJ.

Belobaba, P., Odoni, A., \& Barnhart, C. (2015). The global airline industry. John Wile \& Sons.

Biddle, B.J. \& Martin, M.M. (1987). Causality, confirmation, credulity and structural equation modelling, Child Development, 58: 4-17.

Chiou, Y. C., \& Chen, Y. H. (2010). Factors influencing the intentions of passengers regarding full services and low cost carriers: A note, Journal of Air Transport Management, 16 (4): 226-228. 
Cronin, J.J. Jr and Taylor, S. (1992). Measuring service quality: a re-examination and extension, Journal of Marketing, 56,3: 55-68.

Cronin, J.J. Jr, Brady, M.K. \& Hult, T.M. (2000). Assessing the effects of quality, value, customer satisfaction on consumer behavioral intentions in service environment, Journal of Retailing, 76, 2: $193-216$.

Hair, J.F. Jr, Anderson, R.E., Tatham, R.L. \& Black, W.C. (1998). Multivariate Data Analysis, Prentice-Hall International, Upper Saddle River, NJ.

Heskett, J.L., Jones, T.O., Loveman, G.W., Sasser, W.E. \& Schlesinger, L.A. (1994). Putting the service-profit chain to work, Harvard Business Review, 105-11.

Powpaka, S. (1996). The role of outcome quality as a determinant of overall service quality in different categories services industry: an empirical investigation, Journal of Services Marketing, 10, 2: 5-25.

Reichheld, F.F. \& Sasser, W.E. (1990). Zero defections: quality comes to services, Harvard Business Review, 105-111.

Schmenner, R.W. (1986). How can service businesses survive and prosper? Sloan Management Review, 27,3: 21-32.

Schneider, B. \& Bowen, D.E. (1995). Winning the Service Game, HBS Press, Boston.

Soderlund, M. (1998). Customer satisfaction and its consequences on the customer behaviour revisited: the impact of different levels of satisfaction on word-of-mouth, feedback to the supplier and loyalty, International Journal of Service Industry Management, 9,2: 169-188.

Taksina B. \& Somaya, P. (2017). Consumer behaviour of Thai air traveler's choice for low cost carrier. Suan Sunandha Rajabhat University.

Vorasiha, E. (2018). The travelling route for gastronomic tourism via salt in Western region of Thailand. African Journal of Hospitality, Tourism and Leisure, 7: 1-9.

Zeithaml, V.A., Berry, L.L. \& Parasuraman, A. (1996). The behavioural consequences of service quality, Journal of Marketing, 60,2: 31-46.

Paper submitted

Paper accepted for publishing

Paper published online
26 June 2019

30 August 2019

O1 October 2019 